九州大学学術情報リポジトリ

Kyushu University Institutional Repository

\title{
Envisioning and Observing Women's Exclusion from Sacred Mountains in Japan
}

Dewitt, Lindsey E.

Kyushu University : Visiting assistant Professor

https://doi.org/10.5109/1654566

出版情報：Journal of Asian Humanities at Kyushu University. 1, pp.19-28, 2016-03. Kyushu University, School of Letters, Graduate School of Humanities, Faculty of Humanities バージョン:

権利関係 : 


\title{
Envisioning and Observing Women's Exclusion from Sacred Mountains in Japan
}

\author{
LINDSEY E. DeWITT
}

\section{Exclusion and Ōminesan}

$\Delta$ t $^{\mathrm{T}}$ THIRTEEN-FOOT-TALL stone pillar inscribed with the words "Women's restricted zone from this point on" (kore yori nyonin kekkai 從是女 人結界) stands at the main trailhead to Sanjōgatake 山 上ケ岳, in the Ōminesan 大峰山 mountain range of southern Nara prefecture. Accompanying it is a roughly eleven-foot-tall wooden gate topped by metal spikes that bears the words "Women's restricted zone gate" (nyonin kekkai mon 女人結界門) (Figure 1). Welcoming the prospective visitor before both gate and stone pillar is a signboard roughly six feet tall and three feet wide stating in English and Japanese, "No Woman [sic] Admitted': Regulation of this holly [sic] mountain Ominesan prohibits any woman from climbing farther through this gate according to the religious tradition."

These inscriptions demonstrate the practice of women's exclusion, a widespread cultural phenomenon in Japan. ${ }^{1}$ Elements of gender-exclusive practices can be

1 “Women's exclusion" (nyonin kekkai 女人結界, nyonin kinsei 女人 禁制) denotes a variety of prohibitions against women from entering sites, such as shrines, temples, mountain pilgrimage sites, festivals, sumo platforms, tunnels, or engaging in certain activities, for example brewing sake or firing kilns. In this essay I use the term most often to refer to women's exclusion from mountains. found at many mountains in Japan, especially those like Ōminesan controlled by powerful Buddhist temples. At the same time, our understanding of how restricted zones were established or managed is very limited, as are the ways in which men and women negotiated and contested them in the past and today, or how they changed over time. We know that most territorial proscriptions dissolved in 1872 when the government of the Meiji period 明治時代 (1868-1912) granted women full access to mountain shrine and temple lands, but this reveals only one part of the story. ${ }^{2}$ Female climb-

\footnotetext{
For an overview of the broader phenomenon, see Suzuki Masataka, Nyonin kinsei (Tokyo: Yoshikawa Kōbunkan, 2002), 6-26; and Minamoto Junko, editor, "Nyonin kinsei" Q\&A (Osaka: Kaihō Shuppansha, 2005), 1-10. Women's exclusion from sacred sites (including but not limited to mountains) is a global phenomenon. Mt. Athos in Greece, for example, is a World Heritage-designated sacred mountain that prohibits women's access.

2 According to the May 4, 1872, Grand Council of State Edict 98 (Dajōkan fukoku dai kyū hachi gō 太政官布告第九八號), “Any remaining practices of female exclusion on shrine and temple lands shall be immediately abolished, and mountain climbing for the purpose of worship, etc., shall be permitted" 社佛閣ノ地二 厂女人結界ノ場所有之候処自今被廢止候条登山参詣等可為勝手 事. Naikaku Kanpōkyoku, Hōrei zensho 5(1) (Tokyo: Hara shobō, 1974), 82.
} 


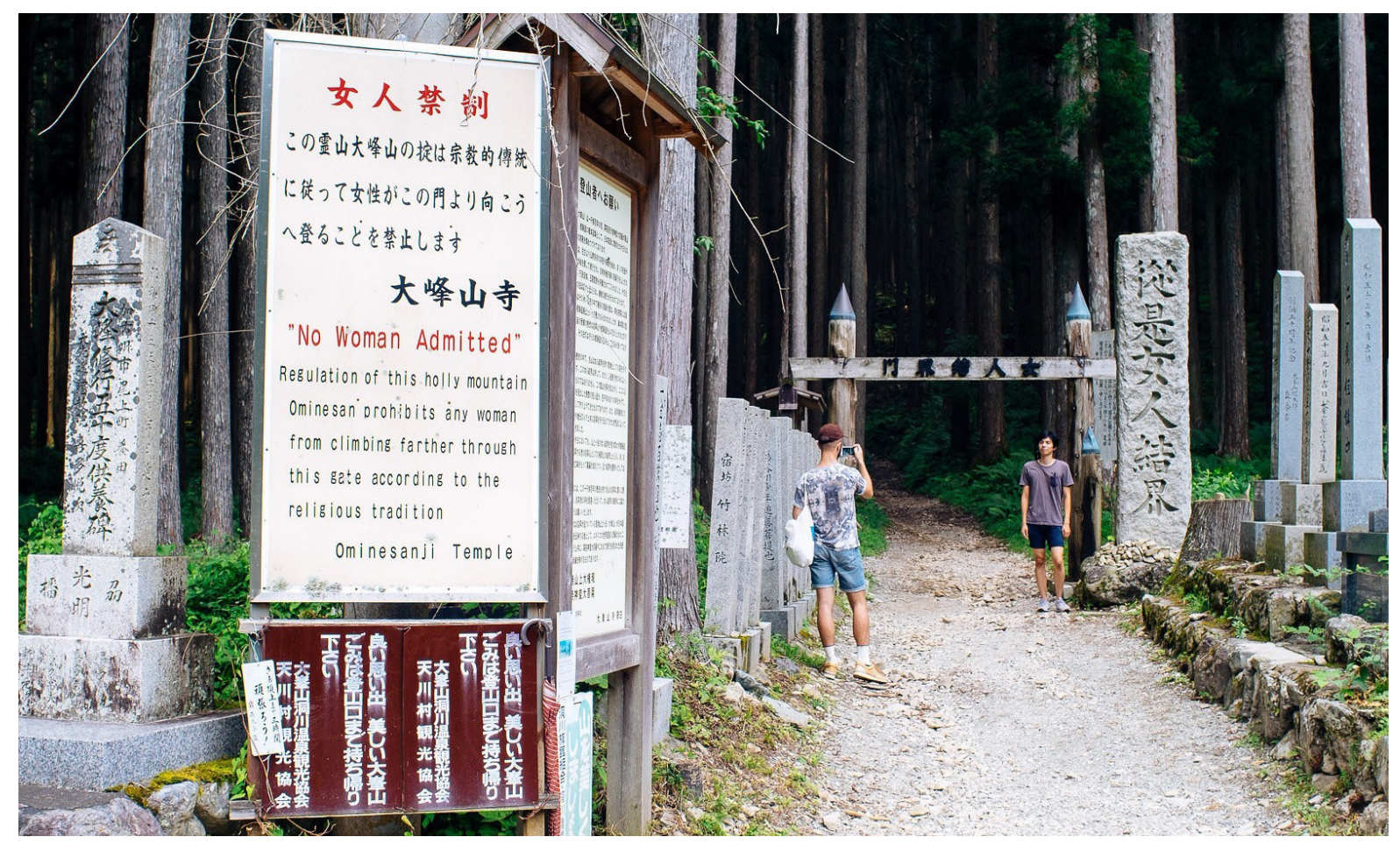

ers were already permitted at Fujisan 富士山 by 1860; at sacred Buddhist Kōyasan 高野山, Wakayama 和歌 山 prefecture, they remained persona non grata until 1906. ${ }^{3}$ The stone and wooden signage at Ōminesan is not physically historical but modern-erected less than fifty years ago-and conceptually inconsistent, indicative of neither a true modern nor ancient history, but instead presenting us with an "imagination," that is, an imagining of the past.

Öminesan, a name synonymous with a mountain range and a single peak, Sanjōgatake 山上ケ岳, is set apart geographically in the Kii 紀伊 peninsula, which consists of several thousands of peaks (Figure 2). It is distinguished in many ways: set apart culturally, imagined in popular and scholarly perceptions as a changeless and timeless place and the spiritual heartland of Japanese mountain religion (Shugendō 修験道), a National Park, and a World Heritage Site. ${ }^{4}$ Ominesan

3 Miyazaki Fumiko, "Female Pilgrims and Mt. Fuji: Changing Perspectives on the Exclusion of Women," Monumenta Nipponica 60 , no. 3 (2005): 340. On the dissolution of the ban at Köyasan, see Washio Junkyō and Jinki Hōju, "Nyonin kekkai no haishi tenmatsu," Gendai Bukkyō, Jūshūnen kinen tokushūgō (1933), 236

4 For studies of Ōminesan's religious history, see Shudō Yoshiki,
Figure 1. Sanjōgatake (peak) main trailhead, Ōminesan. Nara prefecture (Japan). Photograph by the author, 2015.

is also set apart by its exclusionary practices toward women. Women's exclusion, too, is often imagined as changeless and timeless. The term "religious tradition," or shūkyōteki dentō 宗教的伝統, appears frequently on signboards and in conversation to describe, defend, and thus legitimate the ban on women from entering Sanjōgatake. Tradition (dentō) is part of the discourse of modernity in Japan, when practices of the past were

\footnotetext{
Kinpusenji (Tokyo: Meiwa Insatsu Kabushikigaisha, 2004); and Miyake Hitoshi, Ōmine Shugendō no kenkyū (Tokyo: Kōsei, 1988). For a study of Heian-era Ōminesan (Kinpusen), see Heather Blair, Real and Imagined: The Peak of Gold in Heian Japan (Cambridge: Harvard University Asia Center, 2015); and for the Tokugawa period, see Georgios Klonos, "Shugendō in the Tokugawa Period: Mount Ōmine as Imaginary Space and Place of Practice," PhD dissertation (Stanford: Stanford University, 2012). Ōminesan is part of the Yoshino-Kumano National Park formed in 1936. On National Park designation and women's exclusion, see Lindsey E. DeWitt, "A Mountain Set Apart: Female Exclusion, Buddhism, and Tradition at Modern Ōminesan, Japan," PhD dissertation (Los Angeles: University of California, Los Angeles, 2015), esp. 91-108.
} 


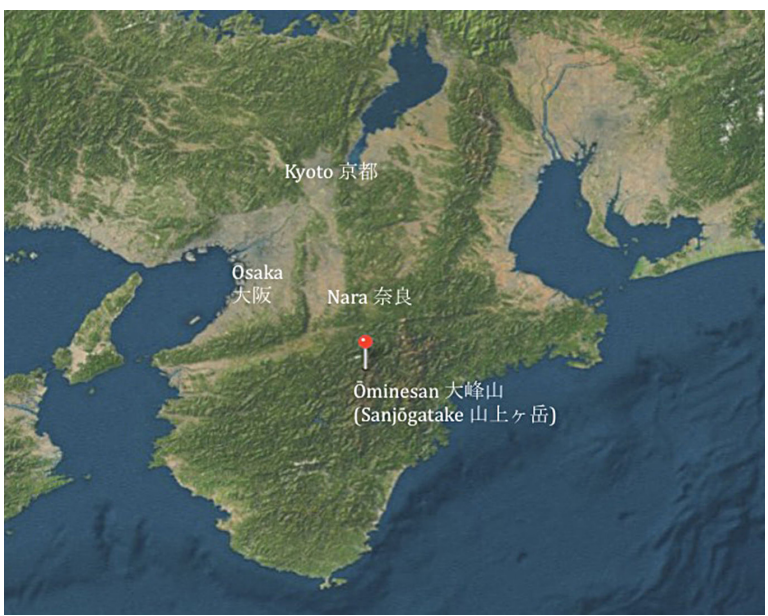

either carefully protected and maintained or redefined and reformulated in the interests of a new juxtaposition of past and present-a resistance to modernity, a promotion of modernity, or elements of both. The mode of historical summation we see at and for Ōminesan suggests a practice of women's exclusion that is ancient and stable. The standard narrative presents a 1300-year practice originating with the layman-cum-saint En no Gyōja 役行者 (634?-701?), who legendarily founded the mountain's wealth of religious practices. The beliefs that paralleled the veneration of En, along with their associated practices, were later defined as Shugendō.

The Yichǔ liùtiě 義楚六帖 (Jpn. Giso rokujō, henceforth cited by the Japanese pronunciation since that is how people in Japan recognize and deploy it) preserves the travel records of the monk Yìchú 義楚 (907-960) in Japan in the year $954 .{ }^{5}$ One short passage paints a vivid portrait of Ōminesan's (given as Kinpusen 金峯山) exceptional elements and exclusive topography:

The Peak of Gold [Kinpusen] lies 500 ri south of Japan's capital. Bodhisattva Kongō Zaō [resides] at the summit. It is the supreme other world. There are pines, cypresses, famed flowers, and strange plants. At several hundred shrines and temples small and large dwell those practicing the Great Way. Women cannot climb it. At present, men afire with the yearning to go up there must abandon

5 Also known as Shishì liùtiě 釋氏六帖 (Jpn. Shakushi rokujō). See Shishì liùtiě 釋氏六帖 (Kyoto: Hōyū Shoten, 1979). The Chinese original can be referenced in Shishì liùtiě (Hangzhou: Zhejiang guji chubanshe, 1990).
Figure 2. Wakayama and Nara prefectures map with the the peak Sanjōgatake, Ōminesan, marked by a red dot. Image adapted from Google Maps.

alcohol, meat, and sex for three months; then all their hearts' desire will be fulfilled. It is said that the [mountain's] bodhisattva is the transformation body of Maitreya, like Mañjuśrī at Wutaishan. ${ }^{6}$

\section{又云ワク。本國都城ノ南五百余里二金峯山有 リ。頂上二金剛蔵王菩薩有リ。第一ノ霊異ナ リ。山二松桧名花軟草有リ。大小ノ寺数百、 節行高道ノ者コレニ居ス。曾テ女人有リテ上 ルコトヨ得ズ。今ニ至リテ男子上ント欲スレ バ、三月酒肉欲色习断ツ。求ムル所皆遂グ。 云ワク、菩薩八是し弥勒ノ化身、五台ノ文殊 ノ如シ.}

The Giso rokujo, and this passage in particular, serves as a font of legitimacy for locals and patrons of the mountain. The passage is universally familiar in the Ōminesan area today. Local residents can easily recount it, and it appears ubiquitously in local literature. The same passage is routinely cited in scholarship on Öminesan, too, where it is offered up as one of the earliest substantiations of female exclusion in Japan. ${ }^{7}$

The present article explores the relationship between this ancient imagination-the imagining-of the mountain and modern realities. The following twopart analysis uses excerpts from the Giso rokujo as focal points to investigate how modern agency transfigures ancient texts: first, the matter of women's exclusion,

6 Ibid, vol. 2, 459

7 Examples can be found in Suzuki, Nyonin kinsei, 124-25; and Taira Masayuki, Nihon chūsei no shakai to Bukkyō (Tokyo: Hanawa Shobō, 1992), 412. 
analyzed in light of contemporary World Heritage literature; second, austerities undertaken by men in preparation for climbing the mountain, considered in view of contemporary access policies.

\section{Reconstructing History: "Women cannot climb it"}

The "Sacred Sites and Pilgrimage Routes in the Kii Mountain Range" UNESCO World Heritage Site, inscribed in 2004, features Ōminesan as a stage for mountain ascetic practices whose reputation as "one of the most sacred mountains in Japan" had reached "as far as China" by the tenth century. ${ }^{8}$ Here, World Heritage literature irrefutably references the Giso rokujō: no other Chinese texts survive that mention Ōminesan. This section examines how the World Heritage vision of Öminesan approaches the mountain's ban on women.

Let us first consider the nominating process of World Heritage Sites, which requires rigorous articulation of a site's exceptional cultural or natural uniqueness. According to UNESCO's operational guidelines, a nomination dossier should provide "all the information to demonstrate that the property is truly of 'outstanding universal value."' Each application requires official state endorsement before it can be submitted to the UNESCO World Heritage Centre in Paris, France, where the International Council on Monuments and Sites (ICOMOS) evaluates it. If an application receives approval, ICOMOS sends an inspectorate to visit the sites under consideration in order to issue an evaluation of the state of conservation (natural and cultural) and site management. ICOMOS also conducts a risk analysis, judging the authenticity and integrity of the claims and compar-

8 ICOMOS, "Dossier for Designation of the Kii Mountain Range as a UNESCO World Heritage Site," No. 1142 (Tokyo/Paris: ICOMOS, 2004), 6. Since its foundation in 1972, UNESCO's World Heritage Convention has designated 1031 properties in 162 countries as such sites. Japan's number of World Heritage Sites totals nineteen to date. The Sacred Sites and Pilgrimage Routes in the Kii Mountain Range was the twelfth to be secured. A complete list of sites and accompanying maps and dossiers can be found at http://whc.unesco.org/en/statesparties/jp (last accessed March 5, 2016).

9 Intergovernmental Committee for the Protection of the World Cultural and Natural Heritage, "Operational Guidelines for the Implementation of the World Heritage Convention" (Paris, 2012), available online at http://whc.unesco.org/archive/opguide12-en. pdf (last accessed March 1, 2016). ing the site with other similar sites. The World Heritage Committee makes the final decision on whether a site deserves World Heritage inscription. In a word, World Heritage status is the culmination of a long and exhaustive process. The nomination that includes Öminesan, for example, was crafted over the course of ten years.

The eight-page evaluation for Ōminesan and other nominated sites in the Kii mountains identifies three issues relating to authenticity: the reconstruction of monuments, visitor facilities, and overhead wires. It also mentions one issue connected to integrity, the discontinuity of the listed pilgrimage routes. ${ }^{10}$ The World Heritage Committee approved the nomination, granting Ominesan World Heritage status, but one very important matter is conspicuously absent from the nomination dossier or any other related literature: women's exclusion. In the carefully crafted 26o-page nomination dossier, which represents almost a decade of planning and approval from within and without Japan, there is not a single mention of the words "woman," "women," "gender," or "exclusion." It is neither hyperbole nor truth to say that the World Heritage Committee simply does not acknowledge the universally recognized discriminatory practice of restricting access to public lands, however, because the status of the lands is not universally agreed upon.

The ICOMOS "team" sent to survey Ōminesan consisted of one person, a male professor from Korea. This came as a great relief in Dorogawa 洞川, today's opening to the main Sanjōgatake trailhead, where residents had decided in advance that if a woman arrived as part of the inspectorate she would be refused entrance to Sanjōgatake, even if it jeopardized the entire World Heritage designation. ." Dorogawa headman Masutani Gen’ichi 桝谷源逸 climbed Sanjoggatake with the Korean professor and described the experience in the following manner: "He asked me, 'OK, I understand the mountain has this tradition.' And I waited. And he asked me, 'Do you think this small gate will be enough to keep them out? Women could just come up here at night and there is nothing to stop them."' Masutani responded that "the same gate had kept them out for 1,300 years." ${ }^{\prime 2}$ The gate in question was actually con-

10 ICOMOS, "Dossier for designation," 39

11 Bruce Wallace, "A Mountain Pilgrimage for Men Only: Tradition Bars Female Climbers," Los Angeles Times, September 4, 2004. Confirmed by the author during fieldwork in Dorogawa. 12 Ibid. 
structed in 1970 when the restricted area was reduced in response to changing economic needs. ${ }^{13}$ The gate described at the opening of the paper (see Figure 1) stands at a newly consecrated site, The Bridge of Great Purity (Seijō ōhashi 清浄大橋), which has no historical record. The 1970 decision resulted in a topographical and conceptual re-mapping of Ōminesan's bounded realm that essentially stripped away the locational significance of a purported 1300-year-old boundary line, theretofore situated at a hall dedicated to En's mother, the Hahakodō 母公堂. Thus, in order to accommodate twentieth-century concerns, historically significant features of the mountain, in tandem with the memory of its religious practices, were and are altered or erased, reconstructing the history of Ōminesan.

In retrospect, Masutani and other proponents of the ban at Ōminesan had little reason to worry about the ICOMOS inspectorate. At the time, however, they certainly did. Many were dismayed at the inclusion of a male-only site, Sanjōgatake, in a World Heritage nomination, and some even mobilized to oppose it. The Nara Women's History Research Group (Nara joseishi kenkyū kai 奈良女性史研究会), for example, held a lecture series in 2001 to discuss gender discrimination in the context of tradition and custom at the mountain. The I-Net Women's Conference of Nara (Ainetto josei kaigi Nara アイネット女性会議なら) presented a report to the United Nations Committee on the Elimination of Discrimination Against Women that same year. ${ }^{14}$ A group called The Association Seeking to Liberate "Ōminesan's Female Exclusion" "“Ōminesan nyonin kinsei" no kaihō o motomeru kai「大峯山女人禁制」の開放を求女 る会; hereafter Motomeru kai) was launched in 2003, led by scholar and advocate Minamoto Junko 源順子. ${ }^{15}$

The Association collected signatures protesting the designation, drawing on the support of a group of female teachers who publicly climbed Sanjōgatake in 1999, members of the Nara Women's History Research Group, and others. In March, Motomeru kai held a symposium to discuss Ōminesan's female exclusion. According to the Association's website, 12,418 signatures were counted as of March 31, 2004. They ranged from women who had climbed Ōminesan to Dorogawa

13 See DeWitt, "A Mountain Set Apart," 27-31.

14 DeWitt, "A Mountain Set Apart," 109.

15 Website for the Association Seeking to Liberate "Ōminesan's Female Exclusion," http://www.on-kaiho.com/action/action_top. html (last accessed March 4, 2016). local people and even male temple priests. In April, Motomeru kai sent the signatures, along with a request to review the legality of female exclusion, to the following parties: the UNESCO World Heritage Commission, Japan's Prime Minister, the Minister of Education, Sports, and Technology (Monbu kagaku daijin 文部科 学大臣), the Minister of Justice (Hōmu daijin 法務大 臣), the Minister of Foreign Affairs (Gaimu daijin 外 務大臣), the Gender Equality Bureau of the Cabinet Office (Naikaku fu danjo kyōdō sankakukyoku 内閣府 男女共同参画局), the Nara Prefectural Government (Nara kenchō 奈良県庁), and the Nara District Legal Affairs Bureau (Nara chihō hōmukyoku 奈良地方法 務局), the mountain's managing temples, lay religious climbing guilds, and the village headmen of the Dorogawa and Yoshino climbing guilds. ${ }^{16}$

The petition asserts, first, that a large sum of public tax money had been used to promote the UNESCO designation. The prefectural budget for World Heritage site promotion and related commemorative projects amounted to roughly eighty-two million yen in 2002 (roughly $\$ 654,000$ ), seventeen million yen in 2003 (roughly $\$ 155,000$ ), and eighty-three million yen in 2004 (roughly $\$ 798,000$ ). It also notes that several roads and trails within the restricted realm occupy public land and had received public funds for repairs. The petition also charged that the ban violated the United Nations Convention for Elimination of All Forms of Discrimination against Women (ratified by Japan in 1985), the Japanese Constitution, and the 1999 Basic Act for a Gender Equal Society (Danjo kyōdō sankaku shakai kihonhō 男女共同参画社会基本法), along with numerous other prefectural and local regulations. ${ }^{17}$

16 http://www.on-kaiho.com/action/contents.html (last accessed March 1, 2016).

17 lbid. The other regulations Motomeru kai noted include the Nara Prefecture Ordinance Concerning Respect for Human Rights and the Abolition of All Discrimination (Nara ken arayuru sabetsu no teppai oyobi jinken no sonchō ni kansuru jōrei 奈良県あらゆる 差別の撤廃及び人権の尊重に関する条例, 1997), Nara Prefecture Ordinance for the Promotion of Gender Equality (Nara ken danjo kyōdō sankaku suishin jōrei 奈良県男女共同参画推進条例， 2001), Yoshinoyama Town Ordinance Concerning Human Rights Protection and the Abolition of All Discrimination (Yoshinomachi arayuru sabetsu no teppai to jinken yōgo ni kansuru jōrei 吉 野町あらゆる差別の撤廃と人権擁護に関する条例, 1997), and the Declaration Concerning "Village Human Rights Protection" ('Jinken yōgo mura' ni kansuru sengen'「人権擁護村」に関する 宣言). This information is available at http://www.on-kaiho.com/ action/20040828 (last accessed March 1, 2016). More information on the United Nations Convention for Elimination of All Forms 
Motomeru kai members even protested on the steps of the Zaō Hall at Kinpusenji on October 13, 2003. None of these efforts, despite their breadth and variety, were effective in halting the nomination. ${ }^{18}$ In fact, a male representative from the tourism office of neighboring Tenkawa Village 天川村, summarily dismissed any efforts to change the ban, remarking that "we cannot touch it [the ban] because it's a religious matter...the citizens' group is completely dismissing the rule of a religion that dates back 1,300 years."19 Ōminesan's managing bodies reaffirmed with a united voice that the mountain would remain closed. Local men installed a new signboard at the main trailhead on April 28, 2014 that framed women's exclusion as an "unquestioned" tradition that "countless people spent over a thousand years building up while revering the sacred mountain."20

Research on World Heritage representations by Sophia Labadi identifies a problematic tendency toward creating "linear, continuous and unilateral presentations of history" that can "omit different perspectives and other histories that might have been linked to the site."21 Indeed, the dossier on Ōminesan crafts an idealized and imaginary vision of the mountain that emphasizes its "outstanding universal value" at the cost of erasing one of its most conspicuous features. This mode of selective remembering extends beyond women's exclusion to include major historical vicissitudes at the mountain, such as the Meiji government's forced separation of buddhas and gods (shinbutsu bunri 神

of Discrimination against Women can be found on the official site http://www.un.org/womenwatch/daw/cedaw/ (last accessed March 4, 2016). For the 1999 Basic Act for a Gender Equal Society, see http://www.gender.go.jp/about_danjo/law/kihon/9906kihonhou.html (last accessed March 1, 2016).

18 A photo of women protesting with banners in Japanese and Korean appears in Fujiwara Tomoyo, "'Ōminesan nyonin kinsei' no kaihō o motomeru undō madeni, dono yō na undō ga arimashita ka", in Minamoto Junko, ed., "Nyonin kinsei" Q\&A (Osaka: Kaihō Shuppansha), 154

19 Yumi Wijers-Hasegawa, "Kii Mountain Range Gambit: UNESCO Heritage Bid Challenged over Gender Bias," Japan Times, May 1. 2004.

20 Quoted in Usui Atsuko, "Tojiru seichi, aku seichi-'Nyonin kinsei/ nyonin kekkai' o meguru giron kara miete kuru mono", Gendai shūkyō, Tokushū "Shūkyō fukkō no chūryū" (2005): 210-11. No photo available but confirmed by other sources.

21 Sophia Labadi, "Representations of the Nation and Cultural Diversity in Discourses on World Heritage," Journal of Social Archaeology 7, no. 2 (2007): 161. No photo is available of the sign, which has since been taken down, but the text and sign have been confirmed in conversation with local residents in Dorogawa.
仏分離) in the late nineteenth century. ${ }^{22}$ The matter of discontinuous pilgrimage routes that appeared in the ICOMOS evaluation as potentially impinging upon the integrity of the nomination was similarly disregarded ultimately. World Heritage literature describes the Okugake 奥駆 as a trail "first constructed in the early 8th century," which "linked the northern and southern sites of Yoshino and Omine, and Kumano Sanzan," despite the fact that Japan's Agency for Cultural Affairs and the prefectural government in Nara have resisted bestowing accolades on the Okugake precisely because it cannot be sufficiently documented as a historical route..$^{23}$

It is difficult to find any reason to discount the claims of Minamoto and Motomeru kai, who point out that UNESCO simply did not regard women's exclusion as an important issue..$^{24}$ At Ōminesan, women's exclusion stood as the important issue to many persons, male and female, and many histories, documented as well as remembered. The process of crafting a World Heritage site is an exercise in collective memory-making and cultural imagining, so how can we account for the absence of women's exclusion in the reports and assessments? We find some clues by looking at the attitudes of local people during the nomination period and during the years following its successful inscription.

Residents of Yoshino 吉野 and Dorogawa, to the north and west of Sanjōgatake, respectively, enthusiastically promoted the designation, proud of the international acclaim bestowed upon the mountain and eager to benefit from increased tourism revenue that a UNESCO designation inevitably guaranteed. A news report in the Los Angeles Times on the heels of the designation notes that Dorogawa headman Masutani proudly showed off "World Heritage site key chains and World Heritage site bells that hang from a climber's hip and tinkle to ward off bears." ${ }^{25}$ A special edition of Kirin Beer was made to celebrate the UNESCO designation.

These examples of "venerative consumption" point

22 Heather Blair, "Zaō Gongen: From Mountain Icon to National Treasure," Monumenta Nipponica 66, no. 1 (2011): 1-47. At other Japanese sacred sites as well, Blair points out, official descriptions feature a "projection of a stable, fertile past," 39.

23 ICOMOS, "Dossier for designation," 36. See also DeWitt, "A Mountain Set Apart," 35 and 113-4.

24 Minamoto was quoted as saying, "UNESCO didn't even seem to think this was an issue." Wallace, "A Mountain Pilgrimage for Men Only."

25 Ibid. 
only in part to what seems to be at stake here. ${ }^{26}$ On the one hand, a World Heritage designation is accompanied by soft power and cultural prestige. On the other, it contributes in a very real sense to local economies, which are heavily dependent on tourism. Women's exclusion, imagined as having occurred in the past and actively enforced in the present, is made history. The designation erases history by endowing a new historyreplete with omissions and new proofs, and bearing the seal of a legitimate (government-approved) and universally recognized cultural organization. Modern agency distorts ancient visions of the mountain. The second part of the following analysis reveals a different type of discordance.

\section{Drawn to Sacrality: "Men afire with the yearning to go up there must abandon alcohol, meat, and sex for three months"}

Scholars have noted that liminal spaces, engendered by boundaries and revealed through transgression, form the bedrock of a site's sacredness. ${ }^{27}$ Bernard Faure, for example, describes an elliptical "logic of transgression" that symbolically undergirds prohibitions against women..$^{28}$ According to this interpretation, exclusion itself sustains the sacredness of a site. But what exactly do these thresholds entail? Who benefits from them? Men climb sacred peaks for a variety of reasons that interweave spiritual and worldly dimensions.

Sarah Thal shows us in the case of Konpirasan 金 比羅山 during the Edo period 江戸時代 (1600-1868) that sacred mountains may have been regarded as ideal sites of numinous purity that women's presence would disrupt, but they were also sites of "chaotic rev-

26 David Chidester and Edward T. Linenthal, American Sacred Space (Bloomington: Indiana University Press, 1995), 4.

27 Abe Yasurō, "Nyonin kinsei to suisan," in "Miko to joshin," Shirīzu josei to Bukkyō 4, edited by Ōsumi Kazuo and Nishiguchi Junko (Tokyo: Heibonsha, 1989), 153-240; D. Max Moerman, Localizing Paradise: Kumano Pilgrimage and the Religious Landscape of Premodern Japan (Cambridge: Harvard East Asian Center), 203; and Bernard Faure, The Power of Denial: Buddhism, Purity, and Gender (Princeton: Princeton University Press, 2003), 245.

28 Faure, The Power of Denial, 245. Discourse on "transgression" and the sacred appears in several works by prominent Western philosophers, but Faure is the first to my knowledge to apply the logic of transgression to the Buddhist context, in the case of not only female exclusion but also gender and sexuality more broadly. See also Faure, The Red Thread: Buddhist Approaches to Sexuality (Princeton: Princeton University Press, 1998). elry" that "served as an escape from the restrictions of everyday propriety" and would be meaningless without women present. ${ }^{29}$ The businessmen from Western Japan who worshipped at the mountain and assured its economic livelihood did not pool community resources or make the arduous journey to the mountain merely to seek respite from the presence of women. Part of the journey was the promise of worldly pleasure. In Thal's words, "vacationing men found the gambling and pleasure quarters of Konpira's inns and brothels constituting one of the main attractions." ${ }^{30}$ A similar situation existed at Ōminesan. Dorogawa's red-light district long operated as an unquestioned part of religious tourism at the mountain. When guilds of laymen and other male travelers began visiting Sanjogatake in large numbers from the early modern period, they seem to have been drawn by both the mountain's perceived sacrality and the threshold of its borders. Dorogawa became the place where male travelers made last-minute preparations for the climb and later availed themselves of worldly pleasures at the many inns and teahouses, where they could call for the services of women.

Significantly, men were not the sole beneficiaries of Ōminesan's liminal spaces, even if they appear to have been the primary stakeholders. Women stood to gain in practical terms, as proprietors, wives, and daughters of local businesses, and in spiritual terms, as recipients of the power of the mountain, which the men who climbed Sanjogatake brought back to town with them. ${ }^{31}$ The prostitutes benefited economically. This local state of affairs changed greatly after anti-prostitution legislation was passed in 1956, and today Dorogawa no longer seems to identify with this kind of practice, even if it still serves to contrast with the sacred realm beyond it with its many teahouses and rest spots.

29 Sarah Thal, Rearranging the Landscape of the Gods: The Politics of a Pilgrimage Site in Japan, 1573-1912 (Chicago: University of Chicago Press, 2005), 114.

30 Ibid.

31 Miyake suggests that many women believed that "mingling" with mountain ascetics after their ascent would strengthen their fertility force. Miyake, Ōmine Shugendō no kenkyū, 7. Others have noted the existence of a widespread belief that ascetics were thought to bring back with them the power of the female mountain god from their climbs and bestow blessings for fertility or heal illnesses. See for example Morinaga Masao, "Shugendō ni okeru 'nyonin kinsei' ni wa, dono yō na mono desu ka", in Minamoto, ed., "Nyonin kinsei" Q\&A, 23-4. 
The boundary line at the foot of Sanjoggatake in Dorogawa marks a threshold where purity, and profanity, were exchanged and negotiated. The exchange and negotiation can be understood to take shape in at least three ways: first, between men and women in the form of union (often sexual acts); second, between men, individually and in groups, in the form of spiritual and bodily abstinence pre-climb and gratification postclimb; and third, from women to men, in the form of fertility and pleasure.

The image of pure-minded men observing rigorous bodily preparations in order to "sip the mist" of the mountains is part and parcel of a body of idealized religious practices at Ōminesan..$^{32}$ It cannot, however, necessarily be reconciled with lived realities at the mountain today-nor, we venture, in times past. The vision of austerities undertaken by men in the oft-cited Chinese text, Giso rokujō, is difficult to substantiate at Öminesan, where men are permitted to enter today without restriction. Here, when expedient, ancient visions of the mountain are disregarded.

\section{Conclusion}

Previous scholarship on women's exclusion has framed inquiries around two main points-origins and early development-and presented a range of theorizations based on a small body of premodern texts, primarily literary, hagiographic, temple regulations. We benefit greatly from the results of textual investigations; they contribute a robust understanding of the mythological, symbolic, and imagined dimensions of restrictions. ${ }^{33}$ But we know very little about the broader context of

32 Heian-period courtier Fujiwara no Moromichi 藤原師通 (10621099) wrote of monks who "sip upon the mist" at Sanjōgatake. Go-Nijō Moromichiki 後二条師通記 (Record of Moromichi of Second Avenue), as it appears in Blair, Real and Imagined, 58. Alcoholic beverages may be purchased in direct proximity to the trailhead at the Bridge of Great Purity, from a vending machine or a small cafe. To watch, as I have, men in religious attire pack coolers of beer at dawn for what ostensibly devolves into a spirit-sipping journey up Sanjōgatake is surely at odds with the notion of religious pilgrimage more widely recognized in religious circles. See DeWitt, "A Mountain Set Apart," esp. 175-80.

33 See Faure, The Power of Denial, 219-49; Moerman, Localizing Paradise, esp. 181-231; Gaynor Sekimori, "Sacralizing the Border: The Engendering of Liminal Space," Transactions of the Asiatic Society of Japan 4, no. 20 (2006): 53-69; Miyazaki, "Female Pilgrims and Mt. Fuji," esp. 340-3; and Blair, Real and Imagined, 48-56. most sources that form the bedrock of various origin theories such as for whom were they written, who was aware of them, or how they reflected and inflected practices on the ground. All we really know is who they were written by: aristocratic men and male clerics. Narrative frameworks construct largely fictionalized ideologies; they are retrospective idealizations that are neither grounded in real contexts nor necessarily aligned with lived realities. These should not be conflated with historical realities, which in the case of women's exclusion are often not well understood. ${ }^{34}$

This paper draws into relief some of the historical contours and complexities concerning women's exclusion at Ōminesan in the modern and contemporary period. Proponents of the ban at Ōminesan today claim legitimation from ancient sources, but as I hope has been amply demonstrated, a clear disjuncture exists between those ancient sources and actual practices. The much-cited tenth-century Chinese account of Öminesan describes it as a peak off-limits to women, but the mountain's exclusionary practices are conspicuously absent from modern acknowledgments of the mountain's unique cultural and religious heritage-even

34 Miyake Hitoshi's massive 700-page study on religion at Ōminesan devotes only four pages to the entire history of female exclusion at the mountain. Miyake, Ōmine Shugendō no kenkyū, 390-394. Miyake is not the only scholar to consider the history of women's exclusion at Ōminesan. Suzuki's Nyonin kinsei devotes roughly fifty pages to historical concerns (28-79). See also Kizu Yuzuru, Nyonin kinsei: Gendai kegare, kiyome kō (Osaka: Kaihō Shuppansha, 1992), 62-136; and Minamoto, "Nyonin kinsei" Q\&A, 134-230. In English, see Sekimori, "Sacralizing the Border;" and DeWitt, "A Mountain Set Apart." Scholars commonly trace women's exclusion from sacred mountains to the ninth century (or some two hundred years earlier according to proponents of the ban at Öminesan today) and assume that it developed along a linear trajectory until the Meiji period or later. The historicity of exclusionary practices has not been convincingly demonstrated in many cases, however. Caleb Carter has pointed out in the case of Togakushisan 戸隠山 in Nagano Prefecture, for example, that medieval texts hint at the real existence of gendered exclusions but overall portray a "highly ambiguous picture of the policy, its physical boundaries and the degree of consensus." Caleb Swift Carter, "Producing Place, Tradition and the Gods: Mt. Togakushi, Thirteenth through Mid-Nineteenth Centuries," (PhD dissertation, Los Angeles: University of California, Los Angeles, 2014), 40. Material evidence (e.g., stone pillars, stele, women's hall) at the mountain, according to Carter, traces back only to the eighteenth century. We find a similar situation at Ōminesan. The earliest physical evidence—a stone pillar at Aonegamine 青根ヶ峰 on the Yoshino side of the mountain-dates to 1865 and bears an inscription that notes it replaced a stone from 1754. A mountain guidebook from 1671 describes that same place but makes no mention of gender prohibition or a stone marker. DeWitt, "A Mountain Set Apart," 55. 
though they remained a matter of central importance beneath the official line. The encounter between women's exclusion and modern cultural imaginings reveals that expediency (often economic) and not cultural or religious transmission alone is a dominant driving force. On the other hand, observing the ambivalent status of purity in the production of Ōminesan's sacred space attests a different kind of discordance. Dorogawa stands at the border between the profane and sacred, but even when the sacred realm is not entirely pure, the perception that it is so (rather than observable realities) remains foremost in the imagination.

These examples cast doubt on the standard interpretive model of ascribing women's exclusion, and also men's inclusion, a largely unquestioned position in Japan's religious landscape. They show that exclusionary practices cannot be properly understood divorced from context. Paying attention to context reveals important historical vicissitudes, and historical vicissitudes are important to the study of women's exclusions for at least three reasons. First, they divulge the work involved in creating and maintaining sacred spaces and their boundaries. This is significant because the social and historical work involved in the making and remaking of this tradition often denies the social and historical changes that made it possible. At Ōminesan, proponents staunchly support the mountain's ban on women as a 1300-year-old religious tradition, and yet in 1970 those same agents sanctioned major reductions to the bounded realm in order to accommodate tourism and other economic interests. ${ }^{35}$ Second, context reveals geographically and culturally contingent agents and arguments. Women's exclusion is not a monolithic entity; it takes on different guises depending on location and situation. ${ }^{36}$ Third, context draws attention to the complex social, political, and economic entanglements that concerned parties such as religious institutions, local residents, patrons, critics, scholars, and others must negotiate. ${ }^{37}$

35 See DeWitt, "A Mountain Set Apart," 27-57.

36 David Chidester offers insightful thoughts on the situational, relational, and contested aspects of sacred space (which I adapt here to women's exclusion). Chidester and Linenthal, American Sacred Space (Bloomington: Indiana University Press, 1995), esp. 1-42.

37 Miyazaki's study of Fujisan in the Edo era highlights the highly contested and often tumultuous dynamic between associations of lay believers, local communities, and the female pilgrims themselves that led to the breakdown of the ban more than two decades before the Meiji edict. Miyazaki also, importantly, points out the economic benefits associated with permitting women's access-they were, after all, paying customers at the
Exclusion exists in social realities and reveals important aspects of the lives of men and the lives of women-it is highly contested and continually reconfigured. Nevertheless, the work involved in the making and remaking of Ōminesan's traditions often denies the historical vicissitudes that underwrite it. This serves as a reminder that, in our analysis of religious landscapes, we need to attend all the more to the social and the historical precisely because the maintenance of religious landscapes is often characterized by the urge to deny the importance or erase the traces thereof. Recognizing these aspects requires us to take care in researching people, places, and religious practices and beliefs, and to question purported history, including recorded history. In so doing we enrich our understanding of the subjects involved and the histories that have yet to come.

\section{Bibliography}

Abe Yasurō 阿部泰郎. “Nyonin kinsei to suisan” 女人禁制 と推参, in "Miko to joshin," Shirìzu josei to Bukkyō 「巫 女と女神」シリーズ女性と仏教4, edited by Ōsumi Kazuo 大隅和雄 and Nishiguchi Junko 西口順子, 153-240. Tokyo: Heibonsha, 1989.

Ambros, Barbara. "Researching Place, Emplacing the Researcher Reflections on the Making of a Documentary on a Pilgrimage Confraternity." Japanese Journal of Religious Studies 36, no. 1 (2009): 167-97.

Blair, Heather Elizabeth. Real and Imagined: The Peak of Gold in Heian Japan. Cambridge: Harvard University Asia Center, 2015.

. "Zaō Gongen: From Mountain Icon to National Treasure," Monumenta Nipponica 66, no. 1 (2011): 1-47.

Carter, Caleb Swift. "Producing Place, Tradition and the Gods: Mt. Togakushi, Thirteenth through Mid-Nineteenth Centuries." PhD dissertation. Los Angeles: University of California, Los Angeles, 2014.

Chidester, David, and Edward T. Linenthal. American Sacred Space. Bloomington: Indiana University Press, 1995.

mountain. Miyazaki, "Female Pilgrims and Mt. Fuji." Exclusionary practices at Ōyama 大山 in Kanagawa prefecture in the late Edo period were molded by a different set of concerns as religious institutions struggled-ultimately unsuccessfully-to keep out not only women but foreigners too. Barbara Ambros, "Researching Place, Emplacing the Researcher Reflections on the Making of a Documentary on a Pilgrimage Confraternity," Japanese Journal of Religious Studies 36, no. 1 (2009): 167-97, esp. 169-70. 
DeWitt, Lindsey E. "A Mountain Set Apart: Female Exclusion, Buddhism, and Tradition at Modern Ōminesan, Japan.” PhD dissertation. Los Angeles: University of California, Los Angeles, 2015.

Faure, Bernard. The Power of Denial: Buddhism, Purity, and Gender. Princeton: Princeton University Press, 2003.

Fujiwara Tomoyo 藤原智代. “'Ōminesan nyonin kinsei” no kaihō o motomeru undō made ni, donoyōna undō ga arimashitaka”大峰山女人禁制」の開放を求め る運動までに、どのような運動がありましたか. In “Nyonin kinsei” QઐA.「女人禁制」Q\&A, edited by Minamoto Junko 源淳子, 152-56. Osaka: Kaihō Shuppansha, 2009.

ICOMOS. Dossier for Designation of the Kii Mountain Range as a UNESCO World Heritage Site. No. 1142. Tokyo/Paris, 2004.

Intergovernmental Committee for the Protection of the World Cultural and Natural Heritage. "Operational Guidelines for the Implementation of the World Heritage Convention.” Paris: WHC-12/o1, 2012.

Katsuura Noriko 勝浦令子. "Women and Views of Pollution." Acta Asiatica 97 (2009): 17-37.

Kizu Yuzuru 木津譲. Nyonin kinsei: gendai kegare, kiyome kō 女人禁制：現代污れ、清女考. Osaka: Kaihō Shuppansha, 1992.

Labadi, Sophia. "Representations of the Nation and Cultural Diversity in Discourses on World Heritage." Journal of Social Archaeology 7, no. 2 (2007): 147-70.

Minamoto Junko 源順子, editor. “Nyonin kinsei” Q\&A「女 人禁制」Q\&A. Osaka: Kaihō Shuppansha, 2005.

Miyake Hitoshi 宮家準. Ōmine Shugendō no kenkyū 大峯 修験道の研究. Tokyo: Kōsei, 1988.

Miyazaki Fumiko 宮崎孔み子. "Female Pilgrims and Mt. Fuji: Changing Perspectives on the Exclusion of Women." Monumenta Nipponica 6o, no. 3 (2005): 339-91.

Moerman, D. Max. Localizing Paradise: Kumano Pilgrimage and the Religious Landscape of Premodern Japan. Cambridge: Harvard East Asian Center, 2005.

Morinaga Masao 森永雅世. “Kindai no ‘Ōminesan’ no ‘nyonin kinsei' ni wa, donoyōnakoto ga okotta no deshōka” 近代の『大峰山』の『女人禁制』には、どのよう なことがおこったのでしょうか. In “Nyonin kinsei” Q\&A「女人禁制」Q\&A, edited by Minamoto Junko源 淳子, 136-40. Osaka: Kaihō Shuppansha, 2005.

Naikaku Kanpōkyoku 内閣官報局編. Hōrei zensho 法令全 書: 5(1). Genshobō, 1974.

Sekimori, Gaynor. "Sacralizing the Border: The Engendering of Liminal Space." Transactions of the Asiatic Society of Japan 4, no. 20 (2006): 53-69.
Shìshì liùtiě 䆁氏六帖. By Yichu 義楚. Giso rokujō 義楚六 帖. Koten sōkan 古典叢刊, vol. 2. Kyoto Hōyū Shoten, 1979.

Shudō Yoshiki 首藤善樹. Kinpusenji 金峯山寺. Tokyo: Meiwa Insatsu Kabushikigaisha, 2004.

Suzuki Masataka 鈴木正孝. Nyonin kinsei 女人禁制. Tokyo: Yoshikawa Kōbunkan, 2002.

Taira Masayuki 平雅行. Nihon chūsei no shakai to Bukkyō 日 本中世の社会と仏教. Hanawa Shobō, 1992.

Thal, Sarah. Rearranging the Landscape of the Gods: The Politics of a Pilgrimage Site in Japan, 1573-1912. Chicago: University of Chicago Press, 2005.

Ushiyama Yoshiyuki 牛山佳幸. “The Historical Development of the Exclusion of Women from Sacred Places (Nyonin Kinzei) in Japan. Acta Asiatica 97 (2009): 39-55.

Usui Atsuko 薄井篤子. “Tojiru seichi, aku seichi—'Nyonin kinsei/nyonin kekkai' o meguru giron kara miete kuru mono”閉じる聖地、開く聖地一女人禁制·女人結界 をめぐる議論から見えてくるもの. Gendai shūkyō 現 代宗教, Tokushū “Shūkyō fukkō no chūryū" 特集「宗教 復興の潮流」: 200-27, 2005.

Wallace, Bruce. "A Mountain Pilgrimage for Men Only: Tradition Bars Female Climbers." Los Angeles Times. September 4, 2004.

Washio Junkyō 鷲尾順敬 and Jinki Hōju 神亀法寿. "Nyonin kekkai no haishi tenmatsu” 女人結界の廃止顛末. Gendai Bukkyō 現代佛教, Jūshūnen kinen tokushūgō 十 周年紀念特輯號 (1933): 230-36.

Wijers-Hasegawa, Yumi. "Kii Mountain Range Gambit: UNESCO heritage bid challenged over gender bias." Japan Times. May 1, 2004. http://www.japantimes.co.jp/ news/2004/05/01/national/unesco-heritage-bid-challenged-over-gender-bias/\#.VlA66t8rL-Y (last accessed March 1, 2016). 